\title{
The effect of hypoxia on exercise tolerance in individuals after acute coronary syndrome treated with angioplasty combined with coronary stent implantation - pilot studies
}

\author{
AGATA NOWAK ${ }^{1, \text { A, B, D-F }}$, CEZARY KUCIO 1, 2, A, D , ZBIGNIEW NOWAK ${ }^{1, \text { A, B, D, E , THOMAS KÜPPER }}$, D, E \\ ORCID ID: 0000-0002-7083-3185 \\ ${ }^{1}$ Department of Physiotherapy at the Jerzy Kukuczka's Academy of Physical Education in Katowice, Poland \\ ${ }^{2}$ Multispecialty Hospital in Jaworzno, Poland \\ ${ }^{3}$ RTWH Aachen University, Aachen, Deutschland
}

A - Study Design, B - Data Collection, C - Statistical Analysis, D - Data Interpretation, E - Manuscript Preparation, F - Literature Search, G - Funds Collection

\begin{abstract}
Summary Background. Currently, there is little documented research evaluating the effect of a high-mountain environment on patients with ischemic heart disease.

Objectives. The main aim of the study was to assess the effect of normobaric hypoxia on exercise tolerance in patients diagnosed with stable coronary disease.

Material and methods. 22 men aged 37 to $72(55.68 \pm 9.86$ years of age) with coronary disease were qualified. In the pre-study, in a normobaric normoxia environment, each patient underwent: resting ECG, spiroergometric test using a treadmill, laboratory tests (gasometry, lactic acid concentration). The patients stayed in the cabinet for 3 hours at the: 1) normoxia, 2) hypoxia (2000 m a.s.l), 3) hypoxia (3000 $\mathrm{m}$ a.s.I.) levels. After the 3-hour period, patients underwent a spiroergometric exercise tolerance test combined with a blood lactic acid concentration test. Venous blood and capillary blood were drawn for gasometry testing purposes.

Results. Under 2000 and $3000 \mathrm{~m}$ hypoxia noted a significantly shorter duration of the exercise test, distance travelled and MET values. An increase in resting blood $\mathrm{pH}$ and a decrease of resting and peak $\mathrm{pCO}_{2}$ and $\mathrm{pO}_{2}$ were observed.

Conclusions. As a result of a 3-hour exposure to normobaric hypoxia, the exercise tolerance of patients after acute coronary syndrome treated with angioplasty combined with coronary stent implantation decreases. There is no clear information for patients as to whether high mountain conditions are safe for them. The presented research was a form of introduction to wider and more thorough experiments that can result in practical information for patients.

Key words: coronary artery disease, hypoxia, angioplasty.
\end{abstract}

Nowak A, Kucio C, Nowak Z, Küpper T. The effect of hypoxia on exercise tolerance in individuals after acute coronary syndrome treated with angioplasty combined with coronary stent implantation - pilot studies. Fam Med Prim Care Rev 2019; 21(2): 117-123, doi: https:// doi.org/10.5114/fmpcr.2019.84547.

\section{Background}

Analysis of the existing research on the topic points to the fact that there are very few documented studies evaluating the effects of a high-mountain environment on patients with coronary disease. Due to the fact that increasingly more individuals decide to spend their free time skiing or mountain hiking, it is to be accentuated that basic safety measures need be taken. These measures apply especially to patients with cardiovascular disease. Patients suffering from coronary disease constitute the largest group of cardiovascular patients and therefore are at the highest risk of reacting to temperature and air pressure changes related to altitude. A study conducted in the Alps in 2011 showed that individuals with a history of stroke, hypertension or coronary disease engaging in sport activities such as skiing and high-mountain climbing were more likely to experience cardiac arrest while staying in a high-altitude environment [1-3]. It was also suggested that staying at an altitude of $3,500 \mathrm{~m}$ a.s.l. in individuals with stable coronary disease and good exercise tolerance, confirmed by an electrocardiographic stress test at sea level, does not pose a risk of sudden cardiac death [1-3]. Nevertheless, it was recommended that the patient undergoes a 3-5-day adaptation period after reaching each new height before progressing to any type of physical exercise, especially sports and recreational activities [4-8]. Moreover, the UIAA Medical Commission summarizes that patients with stable, well-controlled CAD without residual ischemia who participate in unrestricted physical activity at sea level are probably safe to travel up to 3,000 to 3,500 $\mathrm{m}$ with minimal increased risk. Information on the risks to those with CAD who ascend to altitudes above $5,000 \mathrm{~m}$ is lacking, although there are plenty of anecdotal examples of individuals with stable CAD performing well at these altitudes [4]. It should be remembered that if an individual suffering from coronary disease experiences any type of pain during the exercise test, then surely this pain is also expected to occur after reaching even low altitudes, which disqualifies the participant from activities in high-mountain environments [3, 9-11]. It should also be mentioned that this limitation should help the individual avoid visiting a moderate altitude just to enjoy scenery without significant physical activity $[12,13]$. The altitude tolerance of such patients may be tested by breathing hypoxic air at rest in well-supervised conditions (e.g. doctor's practice) [4].

Modern interventional cardiology in combination with a properly adjusted cardiac rehabilitation protocol enables most patients after acute coronary syndrome to undertake physical 
exercise at a level of a healthy individual without major contraindications. Recommendations regarding physical exercise, including the type of exercise, its intensity, frequency and workload for optimal safety of the patient, can be found in PTK and ESC guidelines [14]. However, in the aforementioned guidelines, no indications can be found regarding staying in higher-temperature and humid environments or in environments where changes in temperature and air pressure occur, such as the mountains. Information regarding this topic is of high priority and is more useful than indications regarding physical exercise alone. Physical training has already been widely discussed, and its benefits on the cardiovascular system have been well proven [15-17].

Is it therefore advisable for patients with ischemic heart disease to visit the mountainside? Can patients after full revascularization safely engage in skiing or trekking? Most recommendations regarding staying at high altitudes for this group of patients remain experimental and are not based on scientific evidence. There is a minor amount of reports, mainly from the late 1990s, including results of studies conducted directly at high altitudes on a very limited number of cardiac patients [18-22]. So far, the most comprehensive survey and recommendations have been given by the Medical Commission of the Union Internationale des Associations d'Alpinisme - UIAA (International Mountaineering and Climbing Federation) [4]. These recommendations are as evidence-based as possible.

Despite the fact that the above-mentioned studies were at a significant risk of complications, promising results were obtained. Considering the fact that conducting this type of research requires adequate preparation and medical backup, such as using proper diagnostic equipment, selecting a suitable group of patients, as well as significant financial means due to travelling to mountainsides or constructing a hypoxic cabinet in order to conduct the study in a laboratory environment, amount of reports on the topic is exiguous.

\section{Objectives}

Accordingly, the aim of the following study was to evaluate the effect of normobaric hypoxia on exercise tolerance in patients with coronary artery disease after acute coronary syndrome treated with coronary stent implantation.

\section{Material and methods}

The enrolment for the study took place at the AMED (no explanation for the abbreviation, as it is a proper name) facility in Katowice, in which the second (ambulatory) stage of cardiac rehabilitation of patients with coronary disease after acute coronary syndrome treated with angioplasty combined with coronary stent implantation was performed (Table 1).

To keep the potential risk for the volunteers as low as possible, only patients with stable coronary disease treated with model A cardiac rehab (Table 2) were qualified for the experiment in accordance with the Cardiac Rehabilitation and Exercise Physiology Section of the Polish Cardiac Society guidelines [23]. Cardiac rehabilitation of the participants was applied at least 3 months after acute coronary syndrome (OZW) episode.
Table 1. Coronary angioplasty with stent implantation in study participants after acute coronary syndrome

\begin{tabular}{|l|l|}
\hline Artery & Number of patients \\
\hline LM & $5(22.73 \%)$ \\
RCA & $2(9.1 \%)$ \\
LAD & $8(36.38 \%)$ \\
Cx & $3(13.63 \%)$ \\
D1 & $1(4.54 \%)$ \\
OM1 & $1(4.54 \%)$ \\
LAD + RCA & $1(4.54 \%)$ \\
OM1 + Cx & $1(4.54 \%)$ \\
\hline
\end{tabular}

LM - left main coronary artery, RCA - right coronary artery, LAD - left anterior descending artery, CX - circumflex artery, D1 - first diagonal, OM1 - first obtuse marginal.

\section{Inclusion criteria were:}

- $\quad$ patients after acute coronary syndrome and angioplasty with stent implantation,

- patients with stable coronary disease,

- men aged 35-75 years,

- patients who underwent model A cardiac rehabilitation at least 3 months after the occurrence of acute coronary syndrome,

- patients who gave their consent to partake in the study. Exclusion criteria were:

- unstable coronary disease,

- chronic heart failure during periods of exacerbation,

- resistant hypertension,

- abnormal exercise test results,

- peripheral arterial occlusive disease,

- venous thromboemoblism,

- COPD,

- anemia,

- disorders of locomotor system disabling the patient to take the exercise test,

- lack of consent to partake in the study.

As a result of the above described method of enrolment, 22 patients with diagnosed and clinically documented coronary disease aged $37-72(55.68 \pm 9.86$ years of age) were qualified for the study. In the pre-study, in a normoxia environment, each patient underwent the following tests:

1) resting ECG,

2) exercise test combined with spiroergometric test using a treadmill in accordance with the traditional seven-grade Bruce Protocol,

3) gasometric test.

Each participant entered the hypoxia cabinet 3 times for a period of 3 hours. The testing took place at the Jerzy Kukuczka's Academy of Physical Education Cardiovascular Performance Testing Laboratory. The experiment was conducted in varying oxygen pressure environments:

- $\quad$ normoxia (resembling the air pressure of $350 \mathrm{~m}$ a.s.I., as in Katowice),

- $\quad$ hypoxia (resembling the air pressure of 2,000 $\mathrm{m}$ a.s.I., as on Kasprowy Wierch),

- $\quad$ hypoxia resembling the air pressure of $3,000 \mathrm{~m}$ a.s.I., (as in selected tourist resorts in the Alps).

In accordance with the study protocol, the patients staying in the hypoxic cabinet were not informed about the air pressure

\section{Table 2. Model A cardiac rehabilitation of patients with coronary disease}

\begin{tabular}{|l|l|l|l|l|l|l|}
\hline Model & Risk & $\begin{array}{l}\text { Exercise } \\
\text { tolerance }\end{array}$ & Type of training & Frequency & Total time & Intensity \\
\hline A & low & $\begin{array}{l}>7 \text { MET } \\
>100 \mathrm{~W}\end{array}$ & $\begin{array}{l}\text { continuous endurance train- } \\
\text { ing on a cycloergometer or } \\
\text { treadmill, resistance training, } \\
\text { general fitness exercises }\end{array}$ & 5 days a week & $\begin{array}{l}90 \text { minutes } \\
\text { a day }\end{array}$ & $\begin{array}{l}60 \% \text { to } 80 \% \text { of heart rate } \\
\text { reserve or } 50 \% \text { to } 70 \% \text { of } \\
\text { maximum heart rate }\end{array}$ \\
\hline
\end{tabular}


they were exposed to (single blind design). During the experiment, the participants were provided with an unlimited supply of still mineral water.

After the 3-hour cabinet experiment, each of the participants underwent a spiroergometric exercise test (under hypoxia conditions) with the use of a treadmill, combined with a blood serum lactate concentration test. Moreover, arterialized capillary samples (finger puncture) were drawn in order to perform gasometric lactic acid concentration tests. In order to ensure the safety of the participants during the experiment, a medical rescue team partook in the study.

Exercise tolerance was evaluated with the use of an electrocardiographic submaximal stress test, during which the traditional seven-grade Bruce Protocol was applied.

As established in the study protocol, the pharmacological treatment of patients qualified for the study was optimized and accordant with the guidelines for coronary disease management (Table 3).

\begin{tabular}{|l|l|}
\hline Table 3. Pharmacological treatment of male participants \\
\hline Type of medication & $\begin{array}{l}\text { Number } \\
\text { of patients }\end{array}$ \\
\hline 6-blockers & 15 \\
\hline Clopidogrel & 5 \\
\hline Acetylsalicylicacid (ASA) & 16 \\
\hline Atorvastatin & 2 \\
\hline$\alpha$-blockers & 1 \\
\hline Vitamin K antagonists & 4 \\
\hline Angiotensin II receptor blockers (ARB) & 3 \\
\hline Metformin & 3 \\
\hline Calcium channel antagonists & 2 \\
\hline Angiotensin II converting enzyme inhibitors (ACEI) & 8 \\
\hline Diuretics & 3 \\
\hline
\end{tabular}

Permission of the Bioethics Committee No. 9/2014 at the Jerzy Kukuczka's Academy of Physical Education in Katowice was granted for conducting the study.

\section{Data acquisition}

During the spiroergometric exercise test, the following exercise tolerance values were assessed:

- duration of trial [min],

- distance travelled [m],

- metabolic equivalent [MET],

- peak oxygen consumption $\left[\mathrm{VO}_{2 \text { peak }}\right]$

- peak oxygen consumption $\left[\mathrm{VO}_{2 \text { peak }}\right]$ per kilogram of bodyweight,
- peak minute ventilation [VE]

- resting and peak heartrate.

\section{Gasometric test and lactic acid concentration}

In order to perform a blood gasometry and lactic acid test, the nurse drew approximately $200 \mu \mathrm{l}$ of blood from the fingertip. Test material for gasometry was collected in the hypoxia cabinet twice - the first time at rest and then after the exercise tolerance test. The blood gasometry test was performed using a Bayer Diagnostics Rapidlab284 device.

\section{Statistical analysis}

In order to perform statistical analysis for the study, OpenOffice 4.0.1, StatSoft Statistica 10 and GraphPad Prism 6.07 software were used. The Shapiro-Wilk test and histograms depicting frequency distribution of the studied variable were used in order to evaluate the compatibility of empirical distribution of the studied variables. The homogeneousness of variances was measured pre-analysis using the Brown-Forsyth test. The statistical tools used for verifying the statistical hypotheses were:

- $\quad$ parametric variance analysis with repetitive measurements for variables the distribution of which is compatible with normal distribution, and the variances of the studied groups are homogenous,

- $\quad$ Friedman's non-parametric variance analysis with repetitive measurements for variables the distribution of which is not compatible with normal distribution, or the variances of the studied groups are not homogenous.

For statistically significant results suggesting that median changes in parameter values at varying altitudes differ, the post-hoc Turkey's test for variables of normal distribution and homogenous variances and the Dunn-Bonferroni test for variables exhibiting different than normal distribution and non-homogenous variances were used. The accepted level of significance for the verification of statistical hypotheses amounted to $\alpha=0.05$.

The presented research lasted from April 2017 to the end of the May 2017.

\section{Results}

In both hypoxic and normoxic environments corresponding to an altitude of 2,000 and 3,000 meters a.s.l., none of the patients suffering from coronary disease exhibited adverse symptoms requiring the experiment to be aborted.

\section{Exercise tolerance}

In a hypoxic environment responding to an altitude of 2,000 and 3,000 meters a.s.l. (Table 4), in comparison to normoxia, pa-

\begin{tabular}{|c|c|c|c|c|c|c|}
\hline & 1 & II & III & \multirow{2}{*}{\multicolumn{3}{|c|}{$p$}} \\
\hline & \multirow{2}{*}{$\begin{array}{l}\text { Normoxia } 350 \\
\text { (meters a.s.I. - Katowice) } \\
\mathrm{X} \pm \mathrm{SD}\end{array}$} & \multirow{2}{*}{$\begin{array}{l}\text { Hypoxia } 2000 \\
\text { (meters a.s.I.) } \\
X \pm \text { SD } \\
\end{array}$} & \multirow{2}{*}{$\begin{array}{l}\text { Hypoxia } 3000 \\
\text { (meters a.s.I.) } \\
X \pm \text { SD }\end{array}$} & & & \\
\hline & & & & | vs II & I vs III & II vs III \\
\hline Test duration [min] & $10.70 \pm 2.31$ & $9.53 \pm 1.72$ & $9.31 \pm 2.11$ & 0.001 & 0.000 & 0.711 \\
\hline Distance [m] & $589.03 \pm 199.89$ & $502.70 \pm 171.25$ & $467.61 \pm 164.13$ & 0.000 & 0.000 & 0.498 \\
\hline MET $[\mathrm{ml} / \mathrm{kg} / \mathrm{min}]$ & $8.52 \pm 1.80$ & $7.10 \pm 1.33$ & $6.65 \pm 1.27$ & 0.000 & 0.000 & 0.034 \\
\hline VE [1/min] & $81.92 \pm 22.54$ & $74.09 \pm 21.29$ & $72.80 \pm 21.04$ & 0.244 & 0.174 & 0.847 \\
\hline $\mathrm{VO}_{2 \text { peak }}[\mathrm{l} / \mathrm{min}]$ & $2.51 \pm 0.64$ & $2.06 \pm 0.52$ & $1.86 \pm 0.47$ & 0.001 & 0.000 & 0.034 \\
\hline $\mathrm{VO}_{2 \text { peak } / \mathrm{kg}}[\mathrm{ml} / \mathrm{min} / \mathrm{kg}]$ & $29.63 \pm 6.44$ & $26.27 \pm 8.14$ & $22.04 \pm 4.91$ & 0.029 & 0.000 & 0.042 \\
\hline Lactates 1 [mmol/l] & $1.86 \pm 0.77$ & $1.97 \pm 0.62$ & $1.50 \pm 0.41$ & 0.588 & 0.059 & 0.064 \\
\hline
\end{tabular}




\begin{tabular}{|c|c|c|c|c|c|c|}
\hline & I & II & III & \multirow{2}{*}{\multicolumn{3}{|c|}{$p$}} \\
\hline & \multirow{2}{*}{$\begin{array}{l}\text { Normoxia } 350 \\
\text { (meters a.s.I. - Katowice) } \\
\mathrm{X} \pm \text { SD }\end{array}$} & \multirow{2}{*}{$\begin{array}{l}\text { Hypoxia } 2000 \\
\text { (meters a.s.I.) } \\
X \pm \text { SD }\end{array}$} & \multirow{2}{*}{$\begin{array}{l}\text { Hypoxia } 3000 \\
\text { (meters a.s.I.) } \\
X \pm \text { SD } \\
\end{array}$} & & & \\
\hline & & & & | vs || & I vs III & II vs III \\
\hline Lactates $2[\mathrm{mmol} / \mathrm{l}]$ & $5.49 \pm 2.47$ & $5.30 \pm 2.04$ & $4.81 \pm 2.09$ & 0.786 & 0.322 & 0.432 \\
\hline $\mathrm{HR}_{\text {rest }}[1 / \mathrm{min}]$ & $69.86 \pm 9.08$ & $68.36 \pm 8.35$ & $68.27 \pm 8.61$ & 0.851 & 0.822 & 0.978 \\
\hline $\mathrm{HR}_{\text {peak }}[1 / \min ]$ & $139.68 \pm 15.86$ & $137.40 \pm 11.30$ & $134.77 \pm 13.04$ & 0.584 & 0.266 & 0.475 \\
\hline
\end{tabular}

$\mathrm{VE}$ - minute ventilation, $\mathrm{MET}$ - metabolic equivalent, $\mathrm{HR}_{\text {rest }}$ - resting heart rate, $\mathrm{HR}_{\text {peak }}$ - peak heart rate; 1 - at rest; 2 - at peak physical effort.

tients with coronary disease exhibited a statistically significant decrease in exercise tolerance test duration, distance travelled, MET values and $\mathrm{VO}_{2 \text { peak }}$ per kilogram of bodyweight. Additionally, a statistically significant decrease in MET values and $\mathrm{VO}_{2 \text { peak }}$ per kilogram of bodyweight was noted in hypoxia responding to an altitude of 3,000 meters a.s.l. in comparison to hypoxia resembling a height of 2,000 meters a.s.l. However, no similar differences were observed as far as exercise tolerance test duration and distance travelled during the spiroergometric test are concerned.

No statistically significant changes in ventilation, resting and intra-workout lactate concentration, as well as resting and intra-workout heart rate, were observed (Table 4).

\section{Gasometry}

Blood $\mathrm{pH}$ values increased at a statistically significant manner in the hypoxic environment responding to an altitudes of 2,000 and 3,000 a.s.I. No statistically significant changes were observed in blood $\mathrm{pH}$ values between hypoxic environments of 2,000 meters a.s.I. in comparison to those of 3,000 meters a.s.I. No statistically significant effects of hypoxic environments of 2,000 and 3,000 meters a.s.l. on peak physical effort blood $\mathrm{pH}$ values during the spiroergometric test were noted (Table 5).

No statistically significant effects of a hypoxic environment of 2,000 meters a.s.I. on both resting and intra-workout $\mathrm{pCO}_{2}$ values were observed. However, in the hypoxic environment of 3,000 meters a.s.l., a statistically significant decrease in both resting and peak $\mathrm{pCO}_{2}$ values in comparison to normoxic and hypoxic environments of 2,000 meters a.s.l. were observed. Resting and peak physical effort values of $\mathrm{pO}_{2}$ decreased significantly in hypoxic environments of 2,000 and 3,000 meters a.s.I. Moreover, significantly lower resting and peak $\mathrm{pO}_{2}$ values were noted in the hypoxic environment of 3,000 meters a.s.l. as compared to the environment responding to altitude of 2,000 meters a.s.l. (Table 5).

\section{Discussion}

The evaluation of an organism's reaction to progressively increased physical effort is one of the most important elements of cardiac rehabilitation diagnostics. Stimuli in the form of increasingly demanding physical exercise may incur various disease symptoms, such as early symptoms of heart failure, heart ischemia indicators or cardiac arrhythmia [23].

The comparison of exercise tolerance test results performed in a normoxic environment of 350 meters a.s.l. (Katowice) and those performed in a hypoxic environment of 2,000 and 3,000 meters a.s.l. resulted in various reactions of the participants' organism, adequate to the given circumstances. Resting heart rate values, regardless of the air pressure in the cabinet, were similar. The above may have been a result of the applied pharmacological therapy. As the altitude increases, the oxygen partial pressure - and therefore in the tissues of the body - is reduced, which may cause decreased exercise tolerance, especially in patients with cardio-vascular disease [24]. Beyond the altitude of 1,500 meters a.s.l., peak exercise tolerance is reduced by $1 \%$ with each 100 meters travelled [25-30]. The above thesis has also been proven by proprietary research. During the exercise test, with each new altitude reached, the duration of the test, as well as distance travelled, MET and peak oxygen uptake, dropped significantly in comparison to the normoxic environment. An increase in heart rate related to altitude is one of the organism's reactions to reduced oxygen supply [31]. This phenomenon was also noted in proprietary studies - the patients reached the destined (submaximal) heart rate quicker with each new height above sea level. Although the differences were not statistically significant, the general tendency of the alterations was consistent with the observations of other researchers [22, 31, 32].

Another observed parameter depicting the exercise tolerance level of a participant is peak oxygen uptake $\left(\mathrm{VO}_{2}\right)$ during submaximal physical effort. At high altitudes, a gradual decrease in the human organisms' oxygen uptake capability occurs. In some individuals, this phenomenon can be observed

\begin{tabular}{|c|c|c|c|c|c|c|}
\hline & 1 & II & III & \multicolumn{3}{|l|}{$p$} \\
\hline & $\begin{array}{l}\text { Normoxia } 350 \\
\text { (meters a.s.l. - Katowice) }\end{array}$ & $\begin{array}{l}\text { Hipoxia } 2000 \\
\text { (meters a.s.I.) }\end{array}$ & $\begin{array}{l}\text { Hipoxia } 3000 \\
\text { (meters a.s.I.) }\end{array}$ & & & \\
\hline & $\mathrm{X} \pm \mathrm{SD}$ & $X \pm S D$ & $X \pm S D$ & | vs II & I vs III & II vs III \\
\hline $\mathrm{pH} 1$ & $7.37 \pm 0.03$ & $7.40 \pm 0.02$ & $7.41 \pm 0.01$ & 0.001 & 0.001 & 0.288 \\
\hline $\mathrm{pCO}_{2} 1[\mathrm{~mm} \mathrm{Hg}]$ & $37.55 \pm 4.38$ & $37.17 \pm 2.98$ & $35.37 \pm 3.02$ & 0.744 & 0.018 & 0.004 \\
\hline $\mathrm{pO}_{2} 1[\mathrm{~mm} \mathrm{Hg}]$ & $69.20 \pm 7.35$ & $56.20 \pm 4.95$ & $51.26 \pm 3.77$ & 0.000 & 0.000 & 0.000 \\
\hline $\mathrm{pH} 2$ & $7.30 \pm 0.06$ & $7.33 \pm 0.05$ & $7.31 \pm 0.09$ & 0.174 & 0.741 & 0.512 \\
\hline $\mathrm{pCO}_{2} 2[\mathrm{~mm} \mathrm{Hg}]$ & $35.20 \pm 3.41$ & $34.20 \pm 2.88$ & $32.75 \pm 2.86$ & 0.298 & 0.001 & 0.036 \\
\hline $\mathrm{pO}_{2} 2[\mathrm{~mm} \mathrm{Hg}]$ & $88.64 \pm 13.80$ & $72.43 \pm 7.73$ & $62.35 \pm 7.62$ & 0.000 & 0.000 & 0.000 \\
\hline
\end{tabular}

1 - at rest; 2 - at peak physical effort. 
even at low altitudes (circa 1,400-1,600 meters a.s.I.). Beyond the aforementioned heights, this effect occurs in a linear manner: circa $11 \%$ with each 1,000 meters a.s.l., while at 8,000 , peak oxygen uptake amounts only to $20 \%$ of the value occurring at sea level [33], beginning above the "threshold altitude" of $1,500 \mathrm{~m}[26-30]$

In a study conducted on a group of skiers, a negative correlation was noted between muscle oxidative metabolism indicators (mitochondrial density, intracellular lipid content) and $\mathrm{VO}_{2 \max }$ and maximum effort power indicators evaluated with the use of a progressive exercise test in a hypoxic environment [34]. Other research aimed at explaining the causes of the decrease of $\mathrm{VO}_{2 \max }$ in hypoxemic environment is of interest [35]. In purposefully induced conditions in a hypobaric-hypoxemic cabinet, the effect of various factors likely to impact exercise tolerance with rising hypoxemia were studied. The performed analysis showed that parameters such as sea level $\mathrm{VO}_{2 \max }$ value cause a significant decrease of $\mathrm{VO}_{2 \max }$ in a hypoxemic environment. It was stated that the greater the initial $\mathrm{VO}_{2 \max }$ level, the greater its decline afterwards. The lactate threshold reached at sea level shows an inversed relation - the greater the initial value, the smaller the decline. This finding is somehow difficult to explain. The so-called "lactate paradox" can be excluded, since this effect has been observed at extreme altitudes far beyond 7,000 m only [36]. The indicator causing its decrease during exercise until failure is hemoglobin oxygen saturation $\left(\mathrm{SaO}_{2}\right)$ in hypoxemia; as far as this indicator is concerned, the greater its reduction, the greater the decrease of $\mathrm{VO}_{2 \max }[30]$.

In proprietary studies, $\mathrm{VO}_{2 \text { peak }}^{2 \max }$ given as $\mathrm{I} / \mathrm{min}$ and $\mathrm{ml} / \mathrm{min} /$ $/ \mathrm{kg}$ showed statistically significant changes between all levels at which the studies were conducted. The achieved results confirm the thesis that $\mathrm{VO}_{2 \max }$ declines as oxygen pressure decreases. Similar results were reached in other studies showing a 7-9\% decrease in $\mathrm{VO}_{2 \max }$ with every 1,000 meters a.s.I. [37]. A $19 \%$ drop in peak $\mathrm{VO}_{2 \max }^{2 \max }$ was noted in comparison to the initial value at 540 meters a.s.l. It is to be accentuated that the methodology was similar in these studies in comparison to the proprietary studies: the experiments were conducted once, and the patients' exposure to a hypoxic environment was constant. In turn, different results were reached in cases of exposing the participant to a hypoxic environment in intervals [38].

It also needs to be noted that there are reports in which no significant changes in oxygen uptake in comparison to initial circumstances (normoxia) were noted [39-41]. Moreover, some authors achieved results where peak oxygen uptake increased $[38,42]$. Such disparities in study results were caused by the choice of methodology, time of the patients' exposure to a hypoxic environment and physical effort intensity applied in a hypoxic environment.

During the patients' stay in the hypoxic cabinet, lactate concentration at rest, before the stress test and 4 minutes after the stress test was assessed. During intense physical exercise, significant amounts of lactates are produced (except at extreme altitudes far above of $3,000 \mathrm{~m}$, where our actual study was performed ("lactate paradox", see above)). Maintaining a productive exercise metabolism relies on efficient transportation of the produced lactate and $\mathrm{H}^{+}$ions [36]. A lower lactate concentration in working muscles reduces the feeling of fatigue and facilitates longer periods of physical effort.

According to reports, the ability to regulate $\mathrm{pH}$ levels $\left(\mathrm{H}^{+}\right.$ion concentration) in muscle tissue depends on the amount of buffering alkali [43]. A higher level of buffering alkali may be a part of a fundamental exercise tolerance enhancing mechanism as a result of high-altitude training. A study aiming at evaluating the effect of normobaric hypoxia on the Finnish national sprint team was conducted. It was observed that a 16- to 17 -hour stay in an environment of 2,200 meters a.s.l. causes raised blood $\mathrm{pH}$ levels. After leaving the cabinet, the members of the group, as well as members of the control group, underwent exercise tolerance tests, which showed significant differences in blood lac- tate concentration. The athletes presented lower blood lactate concentration levels in comparison to the control group (7.0 $\mathrm{mmol} / \mathrm{L}$ and $5 \mathrm{mmol} / \mathrm{L}$, respectively) [44]. The achieved results remain fundamentally in accordance with the results obtained by other authors conducting studies involving athletes $[45,46]$. At moderate and high altitudes, anaerobic metabolism is activated during relatively less intensive activity.

In proprietary studies, the only statistically significant differences in blood lactate levels were noted during experiments at altitudes of 2,000 and 3,000 meters above sea level. Participants of the study simultaneously took part in a cardiac rehab program. Most of the patients also engaged in relatively intense physical activity on their own (Nordic walking, cycling, vivid marching, one of the participants was even a parachute jumper) and remained professionally active. It is therefore suggested that a higher blood lactate concentration may have been the result of physical activity undertaken a few hours before the testing.

Researches report mean resting values of $1.3 \mathrm{mmol} / \mathrm{l}$ $( \pm-0.74)$. a.s.l., while at $3,000 \mathrm{~m}$, a tendency to higher concentrations was measured $(1.5 \mathrm{mmol} / \mathrm{l}( \pm-0.36 ; p=0.0758))$, and the increase was highly significant at 4,560 m (2.2 mmol/l ( \pm-0.74 ; $p=0.0015)$ ) [26]. It is suggested that individuals inhabiting low or plain regions and planning to visit high-altitude terrains should develop at least some degree of adaptation through pre-exposure to a hypoxic environment corresponding to 1,500 meters a.s.l. This pre-exposure may be performed in a constant manner, as well as by using the IHE method (Intermittent Hypoxic Exposure) [47]. The IHE method was first introduced in the studies on Finnish athletes as a means of utilizing the ability of the human organism to adapt to hypoxia without the need of burdensome and costly travelling. According to these authors, the degree of acclimatization incurred by this method is directly dependent on the altitude a.s.l., as well as the duration of the stay. As much as 1 to 2 days spent at an altitude of 2,200 meters a.s.l. or 1.5 to 4 hours exposure to a hypoxic environment (cabinet) equivalent to an altitude of 4,000 meters a.s.l. using the IHE method causes the human respiratory system to adapt. During the IHE procedure, patients remain in hypoxic rooms with reduced oxygen. The air is attenuated with nitrogen, filtrated or turned into a hypoxic gas mixture, which in turn resembles the circumstances equivalent to 2,500 to 3,500 meters a.s.I. An increase in total mitochondrial density as result of consistent cycloergometric training in a hypoxic environment corresponding to the height of 3,850 meters a.s.l. is observed [33]. The training was performed for a total of 30 minutes a day, 5 days a week for 6 weeks. Moreover, increases in maximal power and $\mathrm{VO}_{2 m}$ were also noted. However, the latter might be the result of any type of exercise in a sedentary collective.

Peripheral blood gasometry was another studied parameter. Blood was drawn twice: at rest and at peak physical effort. Significant changes were noted between resting blood $\mathrm{pH}$ in a normoxic environment of 2,000 and 3,000 meters a.s.I.

Proprietary research showed that resting and peak effort $\mathrm{pO}_{2}$ values decreased significantly in a hypoxic environment of 2,000 and 3,000 meters a.s.I. Moreover, a significant decrease in resting and peak effort $\mathrm{pO}_{2}$ values at an altitude of 3,000 meters a.s.l. was noted in comparison to the measurements taken at an altitude of 2,000 meters a.s.l. These results remain in accordance with the aforementioned reports [49]. A significant decrease in partial oxygen pressure was noted starting with an altitude of 1,500-2,000 meters a.s.l. and did not affect the health of the studied group. Similar results were achieved in both the control group and in the group of patients diagnosed with coronary disease [48].

Results can be found in literature on the topic pointing to a minor decrease of partial oxygen pressure in our study group. The reason for such a result was the short duration of the stay in a hypoxic environment (lasting only 2.5 hours). The analogous results pertained to the partial pressure of carbon diox- 
ide $\left(\mathrm{pCO}_{2}\right)$. The values decreased as the altitude a.s.l. increased [49].

\section{Limitations of the study}

The presented research is only pilot studies. There is no assessment of the effect on patients in other high-altitude conditions, such as temperature or pressure. It is important to expand the research group in the future.

\section{Conclusions}

As a result of a 3-hour exposure to normobaric hypoxia, the exercise tolerance of patients after acute coronary syndrome treated with angioplasty combined with coronary stent implantation decreases. There is no clear information for patients as to whether high mountain conditions are safe for them. The presented research was a form of introduction to wider and more thorough experiments that can result in practical information for patients.

Source of funding: This work was developed under the research grant "Young Scientists", financed by the Ministry of Science and Higher Education in the year of 2015.

Conflicts of interest: The authors declare no conflicts of interest.

\section{References}

1. Bärtsch P, Simon J, Gibbs R. Effect of altitude on the heart and the lungs. Circulation 2007; 116: 2191-2202.

2. Windsor JS, Rodway GW, Montgomery HE. A review of electrocardiography in the high altitude environment. High Alt Med Biol 2010; 11(1): 51-60.

3. Cheuk-Man Yu, Sheung-Wai L, Ho H, et al. Long-term changes in exercise capacity, quality of life, body anthropometry, and lipid profiles after a cardiac rehabilitation program in obese patients with coronary heart disease. Am J Cardiol 2003; 91: 321-325.

4. Donegani E, Hillebrandt D, Windsor J, et al. Pre-existing cardiovascular conditions and high altitude travel. Consensus statement of the Medical Commission of the Union Internationale des Associations d'Alpinisme (UIAA MedCom) Travel Medicine and Infectious Disease. Travel Med Infect Dis 2014; 12: 237-252.

5. Anderson JD, Honigman B. The effect of altitude-induced hypoxia on heart disease: do acute, intermittent, and chronic exposures provide cardioprotection? High Alt Med Biol 2011; 12(1): 45-55.

6. Faeh D, Gutzwiller F, Bopp M. Lower mortality from coronary heart disease stroke at higher altitudes in Switzerland. Circulation 2009; 120: 495-501.

7. Al-Huthi MA, Raja'a YA, Al-Noami M, et al. Prevalence of coronary risk factors, clinical presentation, and complications in acute coronary syndrome patients living at high vs low altitudes in Yemen. Med Gen Med 2006; 8(4): 28.

8. Naeije R. Physiological adaptation of the cardiovascular system to high altitude. Prog Cardiovasc Dis 2010; 52(6): 456-466.

9. Messerli-Burgy N, Meyer K, Steptoe A, et al. Autonomic and cardiovascular effects of acute high altitude exposure after myocardial infarction and in normal volunteers. Circ J 2009; 73: 1485-1491.

10. Mikulski T. Zastosowanie treningu hipoksyjnego w warunkach nizinnych u lekkoatletów. Sport Wyczynowy 2010; 4: 99 w-105 (in Polish).

11. Kjaergaard J, Snyder EM, Hassager C, et al. The effect of $18 \mathrm{~h}$ of simulated high altitude on left ventricular function. Eur J Appl Physiol 2006; 98: 411-418.

12. Mieske K, Flaherty G, O’Brien T. Journeys to high altitude-risks and recommendations for travelers with preexisting medical conditions. J Travel Med 2010; 17(1): 48-62.

13. Morgan BJ, Alexander JK, Nicoli SA, et al. The patient with coronary heart disease at altitude: observations during acute exposure to 3100 meters. J Wilderness Med 1990; 1(3): 147-153.

14. Guazzi M, Adams V, Conraads V, et al. European Association for Cardiovascular Prevention \& Rehabilitation; American Heart Association. EACPR/AHA Scientific Statement. Clinical recommendations for cardiopulmonary exercise testing data assessment in specific patient populations. Circulation 2012; 126(18): 2261-2274.

15. Gloc D, Mikołajczyk R, Nowak Z. Analiza poziomu tolerancji wysiłkowej chorych po zawale serca w przebiegu 10-letniej obserwacji. Hygeia Public Health 2014; 49(2): 284-290 (in Polish).

16. Podsiadły K, Kowacz K, Niewiadomski P, et al. Ocena wydolności pacjentów poddanych małoinwazyjnemu leczeniu kardiologicznemu. Wpływ metody leczenia na skuteczność programu usprawniania. Rehabil Prakt 2012; 4: 84-87 (in Polish).

17. Nowak Z, Nowak A. Znaczenie aktywności ruchowej w profilaktyce chorób sercowo-naczyniowych cz. 1. Rehabil Prakt 2010; 1: 31-34 (in Polish).

18. Agostoni P, Cattadori G, Guazzi M, et al. Effects of simulated altitude-induced hypoxia on exercise capacity in patients with chronic heart failure. Am J Med 2000; 109: 450-455.

19. Erdmann J, Sun KT, Masar P, et al. Effects of exposure to altitude on men with coronary artery disease and impaired left ventricular function. Am J Cardiol 1998; 81: 266-270.

20. Levine BD, Zuckerman JH, deFilippi CR. Effect of high-altitude exposure in the elderly: the Tenth Mountain Division study. Circulation 1997; 96(4): 1224-1234.

21. Pokan R, Eber B, Fruhwald FM, et al. Physical activity at intermediate altitude by healthy probands and patients with coronary sclerosis. Wien Med Wochenschr 1994; 144: 121-124.

22. Morgan BJ. The patient with coronary heart disease at altitude: observations during acute exposure to 3100 meters. J Wilderness Med 1990; 1: 147-153.

23. Dylewicz P, Jegier A, Piotrowicz R. Kompleksowa rehabilitacja kardiologiczna. Stanowisko Komisji ds. Opracowania Standardów Rehabilitacji Kardiologicznej PTK. Folia Cardiol 2014; 11(Supl. A): 1-48 (in Polish).

24. Strapazzon G, Ponchia A, Ellerton J, et al. Risk assessment and emergency management of coronary heart disease at altitude. High Alt Med Biol 2011; 12(1): 97-98.

25. Fulco CS, Rock PB, Cymerman A. Maximal and submaximal exercise performance at altitude. Aviat. Space Environ Med 1998; 69: 793-801.

26. Küpper T. Workload and professional requirements for alpine rescue [Professoral Thesis]. Aachen: Medical Faculty, RWTH Aachen Technical University; 2006.

27. West JB. Limiting factors for exercise at extreme altitudes. Clin Physiol 1990; 10(3): 265-272.

28. Buskirk ER, Kollias J, Picon-Reatigue E. Physiology and performance of track athlets at various altitudes in the United States and Peru. In: Goddard RF, ed. The international symposium on the effects of altitude on physical performance. Chicago: The Athletic Institute; 1966.

29. Jackson CG, Sharkey BJ. Altitude, training and human performance. Sports Med 1988; 6(5): 279-284. 
30. Buskirk ER, Kollias J, Akers RF, et al. Maximal performance at altitude and on return from altitude in conditioned runners. J Appl Physiol 1967; 23: 259-267.

31. Schmid JP, Noveanu M, Gaillet R, et al. Safety and exercise tolerance of acute high altitude exposure (3454 m) among patients with coronary artery disease. Heart 2006; 92: 921-925.

32. Dehnert C, Bärtsch P. Can patients with coronary heart disease go to high altitude? High Alt Med Biol 2010; 11(3): 183-188.

33. Vogt M, Hoppeler H. Is Hypoxia training good for muscles and exercise performance. Prog Cardiovasc Dis 2010; 52: 525-533.

34. Angermann $\mathrm{M}$, Hoppeler $\mathrm{H}$, Wittwer $\mathrm{M}$. Effect of acute hypoxia on maximal oxygen uptake and maximal performance during leg and upper-body exercise in nordic combined skiers. Int I Sports Med 2006; 27: 301-306.

35. Robergs RA, Quintana R, Parker DL, et al. Multiple variables explain the variability in the decrement in $\mathrm{VO}_{2 \max }$ during acute hypobaric hypoxia. Med Sci Sports Exerc 1998; 30: 869-879.

36. Hochachka PW. The lactate paradox: analysis of underlyingmechanisms. Annals of Sports Medicine 1988; 4: $184-188$.

37. Schmidt W, Prommer N. Impact of alteration in total hemoglobin mass on $\mathrm{VO}_{2 \max }$. Exerc Sport Rev Sci 2010; 38(2): 68-75.

38. Shatilo VB, Oleg VK, Ischuk VA, et al. Effects of intermittent hypoxia training on exercise performance, hemodynamics, and ventilation in healthy senior men. High Alt Med Biol 2008; 9: 43-52.

39. Neya M, Enoki T, Kumai Y, et al. The effects of nightly normobaric hypoxia and high intensity training under intermittent normobaric hypoxia on running economy and hemoglobin mass. J Appl Physiol 2007; 103: 828-834.

40. Julian CG, Gore CJ, Wilber RL, et al. Intermittent normobaric hypoxia does not alter performance or erythropoietic markers in highly trained distance runners. J Appl Physiol 2004; 96(5): 1800-1807.

41. Katayama K, Sato K, Matsuo H, et al. Effect of intermittent hypoxia on oxygen uptake during submaximal exercise in endurance athletes. Eur J Appl Physiol 2004; 92: 75-83.

42. Burtscher M, Pachinger O, Ehrenbourg I, et al. Intermittent hypoxia increases exercise tolerance in elderly men with and without coronary artery disease. Int J Cardiol 2004; 96(2): 247-254.

43. Mizuno M, Savard GK, Areskog NH, et al. Skeletal muscle adaptations to prolonged exposure to extreme altitude: a role of physical activity? High Altit Med Biol 2008; 9: 311-317.

44. Numella A, Rusko H. Acclimatization to altitude and normoxic training improve 400-m running performance at sea level. J Sports Sci 2000; 18(6): 411-419.

45. Astrand PO, Rodahl K, Dahl H, et al. Texbook of work physiology. Champaign (II): Human Kinetics; 2003.

46. Billat VL, Lepretre PM, Heubert RP, et al. Influence of acute hipoxia on time toexhaustion at $\mathrm{VO}_{2 \max }$ in unacclimatized runners. Int J Sport Med 2003; 24(1): 9-14.

47. Rusko H, Leppavuori P, Makla P, et al. Living high, training low. A new approach to altitude training at sea level in athletes (Supplemental Abstract). Med Sci Sports Exerc 1995; 27: 6.

48. Luks A. Should travelers with hypertension adjust their medications when traveling to high altitude? High Alt Med Biol 2009; 10(1): $11-15$.

49. West JB. The physiologic basis of high-altitude diseases. Ann Intern Med 2004; 141: 789-800.

Tables: 5

Figures: 0

References: 49

Received: 10.08 .2018

Reviewed: 19.08 .2018

Accepted: 9.10 .2018

Address for correspondence:

Agata Nowak, PhD

Akademia Wychowania Fizycznego

im. Jerzego Kukuczki

ul. Mikołowska 72A

40-065 Katowice

Polska

Tel.: +48 501 773-925

E-mail: a.nowak88@gmail.com 